Журнал«Герстективита інновації наукц»

(Серія «Гедагогіка», Серія «Гиихологія», Серія «Медицин»»

№2(7) 2022

УДК 159.9:347.96

https://doi.org/10.52058/2786-4952-2022-2(7)-864-869

Заболоцька Світлана Ігорівна кандидат психологічних наук, доцент кафедри психології, Дрогобицький державний педагогічний університет імені Івана Франка, вул.Лесі Українки, 46, м. Дрогобич, 82100, тел.: (097) 029-82-48, https://orcid.org/0000-0003-0686-7185

Заболоцький Назар Дмитрович студент факультету прокуратури, Національний юридичний університет імені Ярослава Мудрого, вул. Пушкінська, 106, м. Харків, 61023, тел.: (068) 086-68-64, https://orcid.org/0000-0002-6077-8514

Богдан Богдан Русланович студент факультету прокуратури, Національний юридичний університет імені Ярослава Мудрого, вул. Пушкінська, 106, м. Харків, 61023, тел.: (096) 635-11-15, https://orcid.org/0000-0002-0545-6264

\title{
ПСИХОЛОГІЧНИЙ ЗМІСТ І СТРУКТУРА ПОНЯТТЯ «ПРАВОВА СВІДОМІСТЬ МАЙБУТНЬОГО ЮРИСТА»
}

Анотація. Демократизація сучасного українського суспільства i гуманізація освіти висувають підвищені вимоги до правової свідомості майбутніх юристів. Від цього залежить їхня соціально-правова, активність, готовність брати участь у зміцненні законності і правопорядку. Проблема розбудови громадянського суспільства, демократичної держави безпосередньо пов'язана із розвитком правової свідомості особистості. Саме правова культура та правове виховання населення є соціальною гарантією дії права в суспільстві. Відзначимо, що наукове мислення та наукова свідомість у взаємодії із правовим мисленням і правою свідомістю особистості здійснюють великий вплив на реалізацію верховенства права в сучасному суспільстві.

Аналіз сучасних досліджень у галузі загальної та юридичної психології свідчить про значну наукову актуальність вирішення проблеми правової свідомості особистості, зокрема фахівця юридичного профілю. Правова свідомість сучасного юриста, на думку багатьох науковців, слід розглядати як особливу форму свідомості, яка, у зв'язку з впливом ряду об'єктивних (соціальних) і суб'єктивних (психологічних) чинників, складається з комплексусу базових правових понять.

У механізмі правового впливу на особистість юриста надзвичайно важливу роль відіграє правова свідомість. Вона посідає проміжне місце серед елементів правового впливу, оскільки формується в людей під впливом різних чинників, у тому числі, правових. Правова свідомість при всій їі різноманітності й недосконалості виступає як засіб регулювання суспільних відносин особистістості [1, с.143]. 
Правова свідомість є сукупністю уявлень, поглядів, переконань, оцінок, настроїв i емоційного ставлення людей до права та державно-правових явищ в суспільстві. Одним із проявів колективної свідомості є групова правосвідомість [3, с.24].

Правова свідомість як форма суспільної свідомості виникає і функціонує як відображення суспільного буття, що пов'язане зі сферою права, правовими відносинами. Цей вид свідомості особистості відображає правову систему іiі життя в суспільстві, як система понять, поглядів, уявлень та ідей, у якій усвідомлюється й оцінюється ставлення людей до дійсності, до самих себе 3 приводу чинного або бажаного права. Також це сукупність соціально-психологічних явищ і процесів, що виражаються у почуттях, настроях, які пов'язані 3 реальним правом. Поняття «право» досить складне - це не тільки юридичний, а й філософський, етичний, соціологічний термін [10].

Ключові слова: правова свідомість, суспільна свідомість, юридична психологія, особистість, правові відносини, мислення, суспільне право, соціально-психологічні явища, суспільне буття, юрист, державно-правові явища.

Zabolotska Svitlana Ihorivna Candidate of Psychological Sciences, Associate Professor of Psychology, 82100, Drogobych, Lesya Ukrainka St., 46, tel.: (097) 029-82-48, https://orcid.org/0000-0003-0686-7185

Zabolotskyi Nazar Dmytrovych Student of the Faculty of the Prosecutor's Office Yaroslav Mudryi National Law University, Kharkiv, 61023, Pushkinska St., 106, tel.: (068) 086-68-64, https://orcid.org/0000-0002-6077-8514

Bohdan Bohdan Ruslanovych Student of the Faculty of the Prosecutor's Office Yaroslav Mudryi National Law University, 61023, Kharkiv, Pushkinska St., 106, tel.: (096) 635-11-15, https://orcid.org/0000-0002-0545-6264

\section{PSYCHOLOGICAL CONTENT AND STRUCTURE OF THE CONCEPT "LEGAL CONSCIOUSNESS OF THE FUTURE LAWYER"}

Abstract. The democratization of modern Ukrainian society and the humanization of education place increased demands on the legal consciousness of future lawyers. Their socio-legal activity, readiness to take part in strengthening law and order depends on it. The problem of building a civil society, a democratic state is directly related to the development of legal consciousness of the individual. It is the legal culture and legal education of the population that is the social guarantee of the operation of law in society. It should be noted that scientific thinking and scientific consciousness in interaction with legal thinking and legal consciousness of the individual have a great influence on the implementation of the rule of law in modern society. 
Legal consciousness plays an extremely important role in the mechanism of legal influence on the personality of a lawyer. It occupies an intermediate place among the elements of legal influence, as it is formed in people under the influence of various factors, including legal. Legal consciousness, for all its diversity and imperfections, acts as a means of regulating the social relations of the individual [1, c.143].

Legal consciousness is a set of ideas, views, beliefs, assessments, attitudes and emotional attitudes of people to law and state and legal phenomena in so ciety.One of the manifestations of collective consciousness is group legal consciousness [3, c.24].

Legal consciousness as aform of social consciousness arises and functions as a reflection of social life, which is related to the field of law, legal relations. This type of individual consciousness reflects the legal system of his li fe in society, as a system of concepts, views, conceptions and ideas, which recognizes and evaluates people\&apos;s attitude to reality, to themselves about the current or desired law. It is also a set of socio-psychological phenomena and processes that are expressed in feelings, moods, which are related to real law. The concept of "law" is quite complex - it is not only a legal but also a philosophical, ethical, sociological term [10].

Keywords: legal consciousness, social consciousness, legal psychology, personality, legal relations, thinking, public law, socio-psychological phenomena, social life, lawyer.

Метою даної статті $є$ обгрунтування психологічних особливостей та напрямів формування правової свідомості майбутніх юристів.

Постановка проблеми. Свідомість людини, відображаючи об'єктивні потреби суспільного розвитку, є передумовою і регулятором поведінки людини. Роль свідомості в регуляції поведінки людини слід розуміти широко: мова йде не тільки про регуляцію поведінки окремо узятого індивіда; регулятивна роль свідомості - це ії дія на всю соціальну систему, в межах якої складаються певні суспільні стосунки, напрям діяльності даної системи. Свідомість як вища форма віддзеркалення суспільного буття додає цілеспрямований характер людській діяльності, дозволяє передбачати іiі результати, планувати поведінку з метою досягнення поставлених завдань. Тому вивчення діяльності, стосунків, поведінки людей - це в той же час вивчення рівня і стану свідомості, що є дуже важлим на сьогоднішній день і потребує грунтовних досліджень науковцями.

Аналіз останніх досліджень і публікацій. Тему правової свдомості досліджували багато науковців, психологів, правознавців та юристів, наприклад: Р. Б. Бедрій, М. І. Суржинський, І. Д. Софінська, М.В. Савчин, Дж. Кохен, К. Хаас та інші. У своїй роботі я дослідив основні підстави набуття та припинення громадянства України.

На думку В.І. Воробйової і І.В. Жданової, зміст свідомості, їі спрямованість детерміновані матеріальними умовами життя людини в суспільстві. 
Віддзеркалення цих умов, пізнання об'єктивних закономірностей суспільного розвитку - важлива функція свідомості. Проте іiі роль не може бути зведена лише до пізнавальної функції. Не менш важливими є організуюча, регулююча функції свідомості, без яких було б неможливе нормальне функціонування соціальної системи людської діяльності, відповідним чином координованої. Організація соціальної системи нерозривно пов'язана 3 функціонуванням свідомості як специфічної діяльності людського мозку, з вивченням природи i функцій як свідомості індивідуального, так і свідомості суспільного [4, с.8-9].

Виклад основного матеріалу. Для виявлення ролі правової свідомості у формуванні соціальної активності людини іï слід вивчати на різних рівнях i зрізах у всьому різноманітті іï прояву i особливостей: як свідомість індивідуальна, групова, суспільна; так і система, що включає різні форми (види) віддзеркалення суспільних стосунків - політичні, правові, етичні, філософські, релігійні [8, с. 37].

М.Л. Гранат підкреслює, що суспільні стосунки людей - це їхня соціальна діяльність, здійснювана у процесі виробництва, перетворення природи, організації повсякденних умов життя, а також ті стійкі взаємозв'язки, які створюються між людьми, між людиною й об'єктивним світом. У виробництві люди вступають у стосунки не тільки з природою, а перш за все утворюють більш - менш стійкі професійні групи для спільної діяльності і для взаємного обміну своєю діяльністю. Свідомість виникає і формується у процесі регулювання соціальної діяльності і дозволяє людині ставити перед собою певну мету, виділяти себе із зовнішнього світу, визначати своє ставлення до предметів і явищ зовнішнього світу $[5$, с. 9$]$.

За визначенням О.М. Бандурки, С.П. Бочарової, О.В. Землянської, правова самосвідомість розглядається як сфера індивідуальної свідомості, що відбиває правову дійсність у формі знань, оцінного ставлення до права і практики його застосування, правових установок i ціннісних орієнтацій, що регулюють людську поведінку в юридично значущих ситуаціях [2, с. 117].

Діяльність юриста носить науково обгрунтований характер, тому в елементному складі професійної свідомості виявляються в певній мірі компоненти теоретичної свідомості. Остання включає наукові знання, ідеї, концепції про суть, характер взаємодії правових явищ, усього механізму правового регулювання. Тому вона може бути названа науковою правосвідомістю. Її рівень визначається глибиною пізнання правових явищ ученими-юристами, політичними діячами, фахівцями в галузі законодавства. У процесі загального і спеціального правового виховання елементи теоретичної правової свідомості організовано вносяться у свідомість мас, під безпосередньою дією якої формується буденна і спеціалізована свідомість [7, с.396].

У вітчизняній психології глибоко обгрунтовується принцип взаємозв'язку свідомості і діяльності. Так, С.Л. Рубінштейн, розкриваючи зміст цього принципу, писав: «Основний позитивний зміст положення про єдність свідомості і діяльності полягає у ствердженні їхнього взаємозв'язку і взаємозумовленості: 
діяльність людини зумовлює формування ії свідомості, психічних зв'язків процесів і властивостей, а ці останні, здійснюючи регуляцію людської діяльності, $є$ умовою іiі адекватного виконання» [3, с. 408]. Реалізація вказаного принципу стосовно дослідження спеціалізованої правосвідомості означає, що ії основні компоненти і особливості повинні бути вивчені в нерозривному зв'язку з професійною діяльністю у сфері правового регулювання відносно застосування права.

Знати всі закони, які ставить перед нами суспільство не можливо. М.В. Савчин вважає, що для правомірної поведінки досить знати правові вимоги, загальні принципи права і керуватися ними у своій поведінці [9]. Інші автори висловлюють думку про загальнообов'язковий рівень правових знань, його мінімуму. У будь якому разі слід мати на увазі, що знання права не повинно зводитися до простої обізнаності про існування тих або інших норм. Знання права передбачає осмислення права, усвідомлення його змісту, визначення його значення для практичної діяльності юриста.

Поведінковий компонент правової свідомості - це правова установка, зміст якої полягає в готовності індивіда практично діяти, проявити активність у галузі пізнання і реалізації права. Правова установка - це динамічний аспект правосвідомості, регулювальник поведінки особистості. У формуванні структури правової установки особистості юриста особлива роль належить iï вольовій активності. Поведінковий елемент акумулює в собі ідеологічний та психологічний елементи і поєднюється з вольовою позицією юриста, з психологічною стороною процесу, практичною діяльністю з досягнення конкретної правової мети [6, с. 101]. Залежно від того, які ідеї, відчуття, уявлення, оцінки, думки домінують у даний момент, можна судити про стан правосвідомості особистості юриста.

Висновки. Таким чином стан правової свідомості майбутніх юристів - це не просто сукупність тих або інших ідей, поглядів, уявлень і відчуттів, емоцій, переконань, оцінок, мотивів діяльності, а таке їхнє розміщення в системі, коли одні з них домінують, визначаючи поведінку юриста.

\section{Лimepamypa:}

1. Алексеев С.С. Философия права / С.С. Алексеев. - М.: Норма, 1997. - 336 с.

2. Бандурка А.М. Юридическая психология: Учебник / А.М. Бандурка, С.П. Бочарова, Е.В. Землянская. - Харьков: Изд-во Нац. ун-та внутр. дел, 2001. - 640 с.

3. Воробйова I.В. Сучасні підходи до проблеми правової свідомості / I.В. Воробйова, I.В. Жданова // Правова свідомість молоді в умовах розбудови демократичної держави в Україні: Матеріали міжвузівського науково-практичного семінару молодих вчених (17 лютого 2006 р., Одеса) / За заг. ред. доктора юридичних наук, професора Долженкова О.Ф. Одеса: ОЮІ ХНУВС, 2006. - С.7-9.

4. Гранат Н.Л. Правосознание и правовая культура / Н.Л. Гранат // Юрист. - 1998. №11 - 12. - С. $7-12$.

5.Ефремова Г.Х. Эмпирическое исследование правосознания: реальное содержание и задачи формирования / Г.Х Ефремова, Н.Л. Гранат // Психологический журнал. - 1988. - №6. - C. $92-102$.

6.Кобець О.В. Структура професійної правосвідомості юриста / О.В. Кобець. // Педагогіка і психологія. Формування творчої особистості: проблеми і пошуки. 3б. наук. пр. Київ; - Запоріжжя, 2005. - Вип. 36. - С. 389 - 398. 
7.Москаленко А.П. Професійна мотивація працівників органів внутрішніх справ: вивчення та корекція / А.П. Москаленко, Д.О. Кобзін, А.А. Стародубцев: - Наук. - практич. посіб. - Х.: Ун-т внутр. справ, 1999. - 98 с.

8.Савчин М.В. Психологічні основи розвитку відповідальної поведінки особистості: автореф. дис... д-ра психол. наук: 19.00.01. / М.В. Савчин. - К., 1997. - 40 с.

9.Соколов Н.Я. Профессиональное сознание юристов / Н.Я. Соколов. - М.: Наука, 1988.-224c.

\section{References:}

1. Alekseev, S.S. (1997). Filosofija prava [Philosophy of Law]. M.: Norma [in Russian].

2. Bandurka, A.M. (2001). Juridicheskaja psihologija [Legal Psychology]. Har'kov: Izd-vo Nac. un-ta vnutr. del [in Russian].

3. Vorobjova, I.V. (2006). Suchasni pidhodi do problemi pravovoï svidomosti [Modern approach to the problem of legal evidence]. Pravova svidomist' molodi $\mathrm{v}$ umovah rozbudovi demokratichnoï derzhavi v Ukraïni: Materiali mizhvuzivs'kogo naukovo-praktichnogo seminaru molodih vchenih (17 ljutogo 2006 r., Odesa) / Za zag. red. doktora juridichnih nauk, profesora Dolzhenkova O.F. - Odesa: OJuI HNUVS, 2006. - S.7 - 9.

4. Granat, N.L. (1998). Pravosoznanie i pravovaja kul'tura [Legal consciousness and legal culture]. Jurist - Lawyer, $11-12,7$ - 12 [in Russian].

5. Efremova, G.H. (1988). Jempiricheskoe issledovanie pravosoznanija: real'noe soderzhanie i zadachi formirovanija [Empirical study of legal consciousness: the real content and tasks of formatio]. Psihologicheskij zhurnal - Psychological journal, 6, 92-102 [in Russian].

6. Kobec', O.V. (2005). Struktura profesijnoï pravosvidomosti jurista [The structure of the professional legal system of a lawyer]. Pedagogika i psihologija. Formuvannja tvorchoï osobistosti: problemi i poshuki - Pedagogy and psychology. Formation of creative specialties: problems and joke, 36, 389 - 398 [in Russian].

7. Moskalenko, A.P. (1999). Profesijna motivacija pracivnikiv organiv vnutrishnih sprav: vivchennja ta korekcija [Professional motivation of practitioners in the bodies of internal rights: education and correction]. X.: Un-t vnutr. sprav [in Ukrainian].

8. Savchin, M.V. (1997). Psihologichni osnovi rozvitku vidpovidal'noï povedinki osobistosti [Psychological foundations for the development of special behavior]. Extended abstract of Doctor's thesis. K., 1997 [in Russian].

9. Sokolov, N.Ja. (1988). Professional'noe soznanie juristov [Professional consciousness of lawyers]. M.: Nauka [in Russian]. 